(C) Dr W. Junk Publishers, Dordrecht - Printed in the Netherlands

\title{
Biomass and density fluctuations of the macrozoobenthos of the intertidal flats in the Oosterschelde, the Netherlands
}

\author{
J. Coosen
}

As part of the BALANS-project the benthic fauna of the Oosterschelde was studied at 8 intertidal stations situated at 3 of the major tidal flats of the area: 3 at the Roggenplaat (in the western part of the Oosterschelde), 1 at the Hooge Kraayer and 4 at the mudflats of the Verdronken Land van ZuidBeveland (eastern part of the Oosterschelde). At each station 15 core samples of $0.0083 \mathrm{~m}^{2}$ were taken to a depth of $30 \mathrm{~cm}$ and washed in the field through a $1 \mathrm{~mm}$ sieve. To establish the density and biomass of the larger sparsely distributed animals the top layer $(10 \mathrm{~cm})$ of a two square meters sampling area was collected and washed through a $3 \mathrm{~mm}$ sieve. The sampling area was further dug out to a depth of $50 \mathrm{~cm}$ and the organisms were sorted by hand. The formalin preserved residues were sorted in the laboratory under a stereo-microscope and all animals were identified to species level, except for the oligochaetes. Ash-Free Dry Weights were determined by standard methods.

Samples were taken from spring 1983 until winter 1984 at three month intervals. Biomass and density-figures for the dominant species are analysed. These species are, in sequence of decreasing biomass: Cerastoderma edule, Arenicola marina, Lanice conchilega, Hydrobia ulvae, Littorina littorea, Macoma balthica, Nereis diversicolor, Scrobicularia plana, Mya arenaria, Nephtys hombergii, Heteromastus filiformis and Scoloplos armiger. They contribute more than $96 \%$ of the total biomass, Mytilus edulis excluded. Mussels are grown on culture plots with high biomass per $\mathrm{m}^{2}$, in the shallow parts of the Oosterschelde, on the slopes of some of the gullies and on some intertidal flats. These were not sampled.
In general biomass values are lowest in February for all stations $\left(10-40 \mathrm{~g} \mathrm{AFDW} / \mathrm{m}^{2}\right)$. Highest biomass values vary considerably from station to station but are generally reached in August-September $\left(25-88 \mathrm{~g} \mathrm{AFDW} / \mathrm{m}^{2}\right)$. In several stations biomass tends to be higher in 1983 than in 1984. As far as data are available a comparison will be made with stations sampled in 1979 till 1981 in the Oosterschelde. Suspension feeders (Cerastoderma edule, Mya arenaria) contribute most to the biomass in about half of the samples, especially from the stations near the mouth of the Oosterschelde. Deposit feeders (Arenicola marina, Macoma balthica and Scrobicularia plana) contribute most in 3 stations, 2 located in the innermost part of the Oosterschelde. Some stations low in the intertidal zone have a high share of filter feeders and some stations high in the intertidal zone have a high share of deposit feeders, but this is no general rule.

Densities vary likewise from station to station and from season to season. Species like Cerastoderma edule have low densities in February/May $\left(50-500\right.$ ind.$\left./ \mathrm{m}^{2}\right)$ and reach their maximum in $\mathrm{Au}-$ gust/September $\left(500-2000\right.$ ind. $\left./ \mathrm{m}^{2}\right)$. Arenicola marina shows little variance over the year except for juveniles in spring on stations high in the intertidal zone, where Heteromastus filiformis and Macoma balthica juveniles also have their highest densities. Other species that will be discussed are: Scoloplos armiger, Nephtys hombergii and Nereis diversicolor.

Finally, distribution, biomass and density of these species is correlated with some abiotic factors like position in the intertidal zone (emersion time), sediment type and organic fraction in the sediment. 